

\section{Sumário}

I. Crônicas do Direito Internacional ...............................................1

REPARAÇÃo DE VÍTIMAS À LUZ DE UM TRATAdo SOBRE EMPRESAS E DIREITOS HUMANOS ............ 3 Ana Cláudia Ruy Cardia

Consumer Social Responsibility as a Requirement for Corporate Social ResponsibiliTY

Nitish Monebhurrun

Crisis in Venezuela: The Brazilian response to the massive flow of Venezuelans in

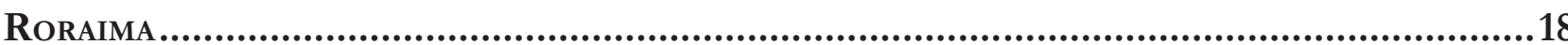

Jacqueline Salmen Raffoul

II. Dossiê EsPecial: Business and Human Rights.........................................23

Some remarks on the third sessions of the Business and Human Rights Treaty Pro-

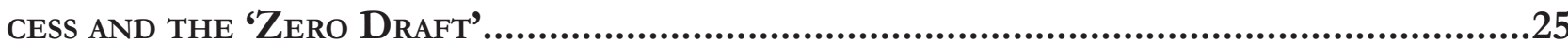

Humberto Cantú Rivera

The United Nations guiding principles on business and human Rights, the State

DUTY TO PROTECT HUMAN RIGHTS AND THE STATE-BUSINESS NEXUS.

Mihaela Maria Barnes

HARdening SOFT LAW: ARE THE EMERging Corporate SOCIAL DisClOSURE LAWS CAPABLE OF GENERATING SUBSTANTIVE COMPLIANCE WITH HUMAN RIGHTS?

Justine Nolan

Del Documento de Elementos al Draft 0: apuntes jurídicos respecto del posible CONTENIDO DEL PROYECTO DE INSTRUMENTO VINCULANTE SOBRE EMPRESAS TRANSNACIONALES

Y OTRAS EMPRESAS CON RESPECTO A LOS DERECHOS HUMANOS

Adoración Guamán 
ACCESS TO REMEDIES AND THE EMERGING ETHICAL DILEMMAS: CHANGING CONTOURS WITHIN THE BUSINESS-HUMAN RIGHTS DEBATE

Justin Jos

LA RESPONSABILIDAD PENAL DE LAS EMPRESAS POR GRAVES VIOLACIONES DE DERECHOS HUMANOS: PRÁCTICA ACTUAL Y DESAFÍOS FUTUROS 130

Daniel Iglesias Márquez

THE ENVIRONMENTAL LAW DIMENSIONS OF AN INTERNATIONAL BINDING TREATY ON BUSINESS AND HUMAN RIGHTS

Juan Gabriel Auz Vaca

Los Objetivos de Desarrollo Sostenible en Europa y su Intersección con el Marco de los Negocios y los Derechos Humanos

Paolo Davide Farah

HumAN RIGHTS AND MARKET ACCESS 203

Danielle Mendes Thame Denny

BusinesS AND HUMAN RIGHTS IN BRAZIL: EXPLORING HUMAN RIGHTS DUE DILIGENCE AND OPERATIONAL-LEVEL GRIEVANCE MECHANiSMS IN THE CASE OF KinRoss PARACATU Gold Mine...222 Mariana Aparecida Vilmondes Türke

Human Rights and eXtractive industries in Latin America: What Responsibility of CORPORATIONS AND THEIR STATES OF ORIGIN FOR HUMAN RIGHTS VIOLATIONS IN THE INTER-American Human Rights System?.

Alberto do Amaral Junior e Viviana Palacio Revello

MultinaCiOnAIS FAST FASHION E DIREITOS HUMANOS: EM BUSCA DE NOVOS PADRÕES DE RESPONSABILIZAÇÃO 255

Laura Germano Matos e João Luis Nogueira Matias

III. Artigos sobre outros temas

EFFICIENCY AND EFFICACY OF PUBLIC FOOD PROCUREMENT FROM FAMILY FARMERS FOR SCHOOL FEEDING IN BRAZIL. 271

Rozane Márcia Triches 
A relaÇão ENTRE O GRAU de INTEGRaÇÃo ECONÔMiCA E O SISTEMA DE SOLUÇÃo DE CONTROvÉRSIAS: UM ESTUdo COMPARATIVO ENTRE A UNIÃo EURopeia E O MERCOSUl.....................286

Luciane Klein Vieira e Elisa Arruda

THE RIGHTS TO MEMORY AND TRUTH IN THE INTER-AMERICAN PARADIGMS OF TRANSITIONAL JUSTICE: THE CASES OF BRAZIL AND CHILE 308

Bruno Galindo

Juliana Passos de Castro

A margem nacional de apreciação na Corte Interamericana de Direitos Humanos.325 Gilberto Schäfer, José Eduardo Aidikaitis Previdellie e Jesus Tupã Silveira Gomes

Novos Direitos FUNDAMENTAIS NO ÂMBITo DA UNASUL: ANÁLISE DAS AGENDAS DE Brasil E VENEZUELA À LUZ DO DIREITO À PAZ.

Pedro Pulzatto Peruzzo e Arthur Ciciliati Spada

A atuação do Grupo Mercado Comum frente À Criminalidade organizada transnacio-

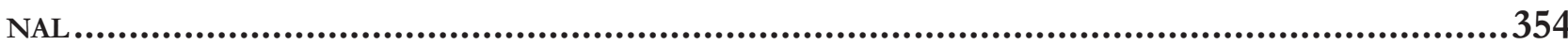

Sabrina Cunha Kesikowski, Luis Alexandre Carta Winter e Eduardo Biacchi Gomes

COUNTER-TERRORISM LEGISLATION AND TERRORIST ATTACKS: DOES HUMAN RIGHTS HAVE SPACE?

Heloisa Tenello Bretas e Daniel Damásio Borges

Territórios da ViolênCia de GÊNERo: NORMATIVA INTERNACIONAL E os Casos "CAMpo AlGodoeiro” (MÉXICO) - “Morro do Garrote” (BrasiL)

Eugênia Nogueira do Rêgo Monteiro Villa e Bruno Amaral Machado

O USO DE MECANISMOS INFORMAIS DE GOVERNANÇA GLOBAL E SUA APLICABILIDADE NAS LICITAÇÕES PÚBLICAS BRASILEIRAS.

Fabiano de Figueiredo Araujo e Paulo Afonso Cavichioli Carmona

Autonomia INSTITUCIONAL DA IGREJA CATÓliCA E A INGERÊNCIA INDEVIDA DO ESTADO BRASILEIRo POR EVENTUAIS Ilícitos CANÔNicos: ANÁlise do CASO de Formosa-GO, À luz do TraTADo Brasil-Santa SÉ de 2010 
A MORE TARGETED APPROACH TO FOREIGN DIRECT INVESTMENT: THE ESTABLISHMENT OF SCREENING SYSTEMS ON NATIONAL SECURITY GROUNDS

Carlos Esplugues Mota

IV. RESENHAS 467

Direito Internacional em Perspectiva Transcivilizacional de Yasuaki Onuma........469 Arthur Roberto Capella Giannattasio

Resenha do livro Space, Global Life: The Everyday Operation of International LaW and Development, de Luis Eslava .473

Matheus Gobbato Leichtweis

QUEM TEM MEDO DO PÓS-COLONIAL NO DIREITO INTERNACIONAL? UMA RESENHA DE "DECOLONISING INTERNATIONAL LAW: DEVELOPMENT, ECONOMIC GROWTH AND THE POLITICS OF UNIVERSAlity" de Sundhya Pahuja

Gabriel Antonio Silveira Mantelli

Direitos humanos COMO UM NOVO PROJETO PARA O Direito INTERNACIONAL? Notas sobre The Last Utopia, de Samuel Moyn .490 João Roriz 


\title{
Counter-terrorism legislation and terrorist attacks: does human rights have space?**
}

\author{
Legislação antiterrorismo e ataques \\ terroristas: têm os direitos humanos espaço?
}

\author{
Heloisa Tenello Bretas** \\ Daniel Damásio Borges***
}

\section{Abstract}

The proposed theory for this study argues that terrorist attacks affect people's perception of security, creating an intense sensation of fear that leads to the support of repressive measures to counter terrorism. Evaluating United States before and after 9/11, this study found that terrorist attacks result in intense perception of danger and a consequent sensation of fear. In turn, this fear led to the support of relaxation of due process, sacrifice of civil liberties in exchange of security, and torture. The legislation analysis presented relaxation of due process rights, especially with the acceptance of illegal evidence, the only indicator that followed the causation process here proposed. Even though it was not found strong support for the theory, the study presents that the fear populations experience after terrorist attacks is connected with high support for the assassination of suspects of terrorism, which was a real surprise. Therefore, campaigns like \#wearenotafraid, are interesting mechanisms to be propagated in order to reduce the sensation of insecurity among citizens and to maintain a certain rationality to calculate the costs and benefits of the measures proposed, not accepting undue restrictions.

Keywords: Terrorism. Counter-terrorism Legislation. Human Rights. Fear. Security.

* Recebido em 30/05/2018 Aprovado em 09/07/2018

** Bacharel em Direito pela UNESP, campus Franca. Mestranda em Direito Internacional Público pela mesma instituição.

E-mail: helotb@hotmail.com

*** Professor de Direito Internacional Público da Faculdade de Ciências Humanas e Sociais da UNESP, campus Franca. Doutor em Direito pela Universidade Paris I Panthéon-Sorbonne (prêmio de melhor tese defendida em 2011 na Escola Doutoral de Direito Internacional Público e Europeu da Universidade Paris I) e Livre-Docente em Direito Internacional Público pela Faculdade de Direito da Universidade de São Paulo (2017). Foi pesquisador visitante na École de Droit de la Sorbonne, Collège de France e no Instituto Universitário Europeu de Florença (2015-2016).

\section{Resumo}

A teoria proposta para este estudo argumenta que os ataques terroristas afetam a percepção de segurança das pessoas, criando intensa sensação de medo que resulta no apoio de medidas repressivas contra o terrorismo. Avaliando os Estados Unidos antes e depois do 11 de setembro, este estudo encontrou que estes ataques resultaram em intensa percepção de perigo e uma conseqüente sensação de medo. Por sua vez, esse medo levou ao apoio do relaxamento do devido processo legal, do sacrifício das liberdades civis em troca de segurança e apoio à tortura. A análise da legislação apresentou o relaxamento dos direitos processuais, especialmente quanto à aceitação de evidências ilegais, o único indicador que seguiu o processo de causalidade proposto. Apesar de não ter encontrado forte apoio para a teoria, o estudo apresenta que o medo das populações após ataques terroristas está ligado ao 
alto apoio ao assassinato de suspeitos de terrorismo, o que foi uma verdadeira surpresa. Portanto, campanhas como \#wearenotafraid, são mecanismos interessantes para serem propagados a fim de reduzir a sensação de insegurança entre os cidadãos e manter certa racionalidade para calcular os custos e benefícios das medidas propostas, não aceitando restrições indevidas.

Palavras-chave: Terrorismo. Legislação contra o terrorismo. Direitos Humanos. Medo. Segurança.

\section{INTRODUCTION}

Terrorism as a phenomenon is older than one might suppose. David Rapoport ${ }^{1}$ proposed an identification of four waves of terrorism throughout history, starting with the Anarchists in the late $19^{\text {th }}$ century, which identified themselves as "terrorists" and used terrorism as a strategy to change public attitudes and conventions. Following, the second wave was marked by "freedom fighters", greatly directed against colonial domain. The radicalism of the third wave, named "New Left Wave", had a revolutionary ethos often combined with nationalist aspirations. Concluding, the author identified the current wave as centered in religious ambitions. Differently from previous movements, the religious radical groups aim to establish a religious New World, and it is important to note that Islam, although highly representative, is not the only religious community producing terrorism.

As one can perceive from Rapoport ${ }^{2}$ historical evaluation, terrorism has been used to address quite different phenomena, at distinct historical periods, with varied methods. Nonetheless, terrorism as a method of violence, lacks a definition universally accepted. Angli ${ }^{3}$ argues that, although a concept broadly used in political discourse and mass media articles, the characteristics that terrorism entangles are not unanimously agreed in

1 RAPOPORT, D. The four waves of rebel terror and September 11. Anthropoetics, v. 8, n. 1, Spring/Summer 2002. Available on: $<$ http://anthropoetics.ucla.edu/ap0801/terror/>.

2 RAPOPORT, D. The four waves of rebel terror and September 11. Anthropoetics, v. 8, n. 1, Spring/Summer 2002. Available on: $<$ http://anthropoetics.ucla.edu/ap0801/terror/>.

3 ANGLÍ, M. L. What does terrorism means? In: MASFERRER, A.; WALKER, C. Counter-terrorism, buman rights and the rule of law: crossing legal boundaries in defence of the state. Cheltenham: Edward Elgar, 2013. p. 18. most national and international criminal law. The author presents that the act of violence itself is usually already prescribed within common criminal legislation, like bombing a building, however, what categorizes it as a terrorist act is the creation of collective fear that affects the perception of security of all members of society, sending a communiqué that as long as status quo remains, other acts of terrorism will happen. Additionally, the element of randomness of terrorist attacks implies that its victims have just a symbolic meaning, as a message that anyone can be the next victim. In this scenario, the subjective sense of security is greatly affected, even though, objectively, the chances of dying from other causes are much higher".

Hence, there is a general understanding among scholars $^{5}$ that terrorist attacks like 9/11 greatly affect the states' ability to protect its citizens and undermine the democratic ways of problem solving. Nonetheless, although terrorist violence presents itself as a serious challenge to democratic countries, Hoffman ${ }^{6}$ argues that it does not threaten the very existence of governmental institutions, the civil community, or the life of the nation. As Paul Wilkinson observed, "it is part of the price we must pay for our democratic freedoms that some may choose to abuse these freedoms for the purposes of destroying democracy, or some other goal"'

This, however, is not the main understanding among citizens, politicians and international organizations. Shortly after the 9/11 attacks, George W. Bush launched the "War on Terror", and the Security Council (hereafter UNSC) adopted the Resolution 1373 urging all countries to unite in the international fight against

4 ANGLÍ, M. L. What does terrorism means? In: MASFERRER, A.; WALKER, C. Counter-terrorism, buman rights and the rule of law: crossing legal boundaries in defence of the state. Cheltenham: Edward Elgar, 2013. p. 20, 22, 23.

5 See generally DOUGLAS, R. Law, liberty, and the pursuit of terrorism. Ann Arbor: The University of Michigan Press, 2014.; MASFERRER, A.; WALKER, C. Countering terrorism and crossing legal boundaries. In: MASFERRER, A.; WALKER, C. Counter-terrorism, buman rights and the rule of law: crossing legal boundaries in defence of the state. Cheltenham: Edward Elgar, 2013.; WILKINSON, P. Terrorism versus democracy: the liberal state response. 3. ed. Taylor \& Francis, 2011.

6 HOFFMAN, L. A v Secretary of State for the Home Department. UKHL. 56 para 96, 2004.

7 WILKINSON, P. Terrorism versus democracy: the liberal state response. 3. ed. Taylor \& Francis, 2011. p. 220.

8 THE GUARDIAN. Text of George Bush's speech: State of the Union Address. The Guardian, sept. 21, 2001. Available on: <https:// www.theguardian.com/world/2001/sep/21/september11.usa13>. 
terrorism with preventive measures of suppression against anyone that participates in "financing, planning, preparation or perpetration of terrorist acts", in line with the perception that the existent legal responses within national criminal law were not sufficient to deal with the threat of radicalism. Even though the nations were urged to comply with the international fight against terrorism, neither the Resolution 1373 nor the subsequent ones provided a definition of terrorism generally accepted. These instruments specify only the consequences of terrorism, a rather narrow approach to this complex and multifaceted phenomenon. Therefore, there is a prevailing understanding ${ }^{10}$ among scholars as Sarah Pellet, Antonio Cassese and Gilbert Guillaume, that adequate answers to terrorism depend upon the establishment of an internationally recognized definition, and that the lack of it has compromised the capacity of both countries and international community to respond effectively ${ }^{11}$, frequently with "solutions" that comply with instruments as Resolution 1373 but in detriment of human rights.

Masferrer presents that when faced with the radical violence of $9 / 11$ with sub-sequential incidents in other locations, and the call to enter the "war on terror", frequently to do whatever it takes, several countries decided to enter it. The author explains that modern western constitutionalism considered rights as natural, pre-political in character, which means that the very existence of the State was justified in the recognition and protection of these rights. However, the radicalism

9 UNSC. United Nations Security Council Resolution 1373. Adopted by the Security Council at its 4385th meeting, on 28 September 2001. p. 2. Available on: <https://www.unodc.org/pdf/crime/terrorism/res_1373_english.pdf $>$.

10 Legal Analyst and attorney Jennifer R. Breedon, among other scholars as Daniel Goldhagen (Goldhagen, Daniel Jonah, Worse Than War: Genocide, Eliminationism, and the Ongoing Assault on Humanity. Public Affairs Publisher, 1st ed. 2009), argues that modern violent extremist groups have eliminationists purposes and intend to fulfill them through international crimes as genocide, conspiracy to commit genocide and crimes against humanity, which are all already universally defined. For this reason, she understands that a universally accepted definition of "terrorism" is unnecessary, given that the States have the courage to call these crimes by their names, "genocide", and properly prosecute them before international courts and tribunals. See more at BREEDON, Jennifer. Redefining terrorism: the danger of misunderstanding the modern world's gravest threat. Revista de Direito Internacional, Brasília, v. 12, n. 2, 2015 p. 463-483.

11 PELLET, S. A ambiguidade da noção de terrorismo. In: BRANT, L. N. C. (Coord.). Terrorismo e direito: os impactos do terrorismo na comunidade internacional e no Brasil. Rio de Janeiro: Forense, 2003. p. 9, 13, 14, 18. of the $21^{\text {st }}$ century found states where human rights are based in democratic consensus, socially contracted, with the possibility of rights' derogation, which raised the discourse of an "irreconcilable" struggle between state security and the freedoms of its citizens ${ }^{12}$.

Thus, liberal democracies' legal responses to this challenge have distinct character. Some responses may have a prophylactic aim, implementing reforms in areas that otherwise could lead to grievances and maybe even violence. A statute giving greater autonomy for the Basque region adopted in 1978 by the Spanish Parliament represents this kind of preventative attempt. Other laws may aim to deter, stipulating harsh penalties for terrorist acts, like aircraft hijacking. However, what we are interested in this study is to analyze the legal measures that aim to reassure the citizens that something is being done, mainly with a symbolic or psychological function of making the state safer ${ }^{13}$. Roger Douglas argues that prompted by this necessity of reaction from the public, or by the perception of its intense fear, the executive and legislative sometimes come up with opportunistic strategies incompatible with liberal values of liberty and justice that would otherwise be politically unaccepta$\mathrm{ble}^{14}$.

Although the executive and legislative might act upon false pretenses - adopting legal measures only to show that there is response against terrorist violence or seizing the moment to take repressive measures -, either way, the general population accepts and even urges for security measures. For this reason, this study aims, focusing on the United States (US) as a case study, to assess the effects of terrorism on counter-terrorism legislation and its respect of human rights standards through an evaluation of citizens levels of fear following violent radicalism. In addition, it hopes to be relevant to the field of peace and conflict research furthering the understandings on the effects of terrorism on societies, as well as furthering the juridical debate upon counter-terrorism laws.

12 MASFERRER, A. The fragility of fundamental rights in the origins of modern constitutionalism: its negative impact in protecting human rights in the "war on terror" era. In: MASFERRER, A.; WALKER, C. Counter-terrorism, human rights and the rule of law: crossing legal boundaries in defence of the state. Cheltenham: Edward Elgar, 2013. p. 50-51.

13 WILKINSON, P. Terrorism versus democracy: the liberal state response. 3. ed. Taylor \& Francis, 2011. p. 92-93.

14 DOUGLAS, R. Law, liberty, and the pursuit of terrorism. Ann Arbor: The University of Michigan Press, 2014. p. 1-2. 
Therefore, the research question is "How does terrorist attacks possibly affect the respect of human rights standards in national counter-terrorism legislation, especially the US legislation?”

After a brief historical introduction of terrorism, the problems of its definitions, and the responses from national and international community, the next sections will have the following structure. In the Theory part we will address the definition of terrorism adopted in this study, the independent and dependent variables, the causal mechanism that we expect to exist between them, and how do we expect them to influence each other. In the sequence, the Research Design part will contain my strategy to case selection, operationalization of the independent and dependent variables, sources of data collection and explanation of the chosen method of analysis. The last two sections will present and discuss the results obtained and their possible interpretations, summarizing the outcomes and future possibilities following this research.

\section{THEORY}

In this paper, for pragmatic reasons, we will adopt the following Bruce Hoffman's definition of terrorism:

\begin{abstract}
We may therefore now attempt to define terrorism as the deliberate creation and exploitation of fear through violence or the threat of violence in the pursuit of political change. All terrorist acts involve violence or the threat of violence. Terrorism is specifically designed to have far-reaching psychological effects beyond the immediate victim(s) or object of the terrorist attack. It is meant to instill fear within, and thereby intimidate, a wider "target audience" that might include a rival ethnic or religious group, an entire country, a national government or political party, or public opinion in general. Terrorism is designed to create power where there is none or to consolidate power where there is very little. Through the publicity generated by their violence, terrorists seek to obtain the leverage, influence, and power they otherwise lack to effect political change on either a local or an international scale. ${ }^{15}$
\end{abstract}

Nonetheless, we should emphasize that this is not an incontestable definition. The aspects considered especially important for this research are that terrorism include violent actions by groups that have specific mo-

15 HOFFMAN, B. Inside terrorism. New York: Columbia University Press, 2006. v. 2. p. 40-41. tivations, but that, generally, have random targets that function as messengers of the group's aims to the main target, e.g. a country's population, and, finally, that the groups try to propagate their aims through the creation of a terror atmosphere.

This study assumes, therefore, that terrorist violence aims to create psychological conditions of fear amongst a general population, not only the immediate victims, influencing their attitudes and intimidating governments ${ }^{16}$. Building upon Alex Braithwaite ${ }^{17}$ assessment that terrorist attacks do change the mindset of countries' citizens creating fear, however, contrary to Long's affirmation that terrorists "use the unreasonable fear and the resulting political disaffection it has generated among the public to intimidate governments into making political concessions in line with its political goals" ${ }^{18}$, we aim to show that instead of giving in to the demands of radicals, the psychological violence creates an intense sense of fear that leads to the application of the precautionary principle instead of a cost-benefit analysis, which makes citizens urge for security measures and, at the same time, prevents them to rationally assess the costs and actual benefits from the legal measures adopted, influencing the content of these laws, and agreeing with reductions imposed on their own rights.

Henceforth, the theory of this study is that terrorism, materialized in terrorist attacks ${ }^{19}$, negatively affects the content of national counter-terrorism legislation, which becomes less respective of human rights standards because these acts of psychological violence create an intense sense of fear not only in the direct victims, but, most importantly, in the general population, that for this reason perceives the existent criminal rules as not enough protection and, with the mentality that it is "better to be safe than sorry", perceives as necessary to have "tougher" anti-terrorism laws, even if there is no proven connection between less protection of hu-

16 FRIEDLAND, N.; MERARI, A. The psychological impact of terrorism: a double-edged sword. Polit Psychol, v. 6, p. 591-604, 1985. p. 591-604.

17 BRAITHWAITE, A. The logic of public fear in terrorism and counter-terrorism. Journal of Police and Criminal Psychology, v. 28, p. 95101, 2013. DOI 10.1007/s11896-013-9126-x.

18 LONG, E. The anatomy of terrorism. New York: Free Press, 1990. p. 5.

19 Although we believe that threats of terrorist violence also have an effect upon populations and countries not directly affected, we can not say that the effects are the same of actual attacks, and assessing the difference would be rather complex for this paper and its limited length, aside from diverting slightly from the chosen focus. 
man rights and actual prevention of terrorist attacks.

For this study, terrorist attacks of violence will be considered the independent variable, whilst the dependent variable will be evaluated through the possible existence of changes in the counter-terrorism legislation regarding their respect for human rights standards. The expected relationship between the variables, the causal mechanism, would be the fear that terrorist attacks may generate in a country's population and its consequent support for the adoption of the precautionary principle in legal measures as a means of protection.

The scope conditions of this theory are fully democratic countries that suffered international terrorist attacks. Thus, the relevant population for this research are countries that experience both at the same time. This study assumes that in fully democratic countries the citizens' aspirations have a saying into the policies and legal measures adopted because of the its free election of representatives. These countries also limited our choice once we assume that democracies are more committed with upholding human rights in their territory. The occurrence of international terrorist attacks is also a limitation, excluding countries that suffer from national terrorism, once we assume that these phenomena have rather different aims and impact nationwide. National terrorism relates to internal grievances and local disputes that usually divide its citizens between supporters and non-supporters, which is rather different from $\mathrm{Al}$ Qaeda's jihadist fight with random victims, for example.

The precautionary principle, according to Hahn and Sunstein ${ }^{20}$, is a mindset directed to the avoidance of risk. It is a risk averse approach to complex and possibly harming situations, resumed by the old saying "better safe than sorry". The authors argue that this mindset can be harmful for a couple of reasons, one of them is exemplified in a declaration given in a meeting of environmentalists in 1998: "When an activity raises threats of harm to human health or the environment, precautionary measures should be taken even if some cause and effect relationships are not fully established scientifically" ${ }^{\prime 21}$. The statement presents that, guided by the precautionary principle, scientific uncertainty of the

20 HAHN, R. W.; SUNSTAIN, C. R. The precautionary principle as a basis for decision making. The Economists' Voice, v. 2, n. 2, article $8,2005$.

21 HAHN, R. W.; SUNSTAIN, C. R. The precautionary principle as a basis for decision making. The Economists' Voice, v. 2, n. 2, article 8, 2005. p. 1 . relationship between a threat and its possible harms is not a reason not to take or to postpone preventive measures, even if these actions could greatly affect society. In an attempt to be safer at any costs, these measures should be taken before the actual understanding of the causality chain, which the authors present as possibly leaving the real risks inadvertent and the question "how safe is safe enough?" open for unlimited measures. Their view is that we cannot afford to live in a risk-free environment because preventative measures may as well create other risks or be unfeasible, as would be banning air travel to eliminate a possible source of hijackings.

Although, in its origins, the precautionary principle was directed to environmental law and regulation, becoming an established principle by instruments like the Rio Declaration on Environment and Development $1992^{22}$, according to Lennon ${ }^{23}$, "precautionary measures in counter-terrorism are not new", what is indeed new is the articulation of these measures as precautionary. Through the lens of Stern and Wiener ${ }^{24}$, applicating the precautionary principle in countering terrorism is not unreasonable, given the potential for harm resulted from a terrorist attack and the uncertainty of threat's materialization. They argue that counter-terrorism "frequently operates on the basis of incomplete, even sketchy, evidence or hints of planning by secretive, shadowy groups whose true intentions, capacities,

22 The Principle 15 of the Rio Declaration on Environment and Development 1992 has the following terms: "In order to protect the environment, the precautionary approach shall be widely applied by States according to their capabilities. Where there are threats of serious or irreversible damage, lack of full scientific certainty shall not be used as a reason for postponing cost-effective measures to prevent environmental degradation." Retrieved from: <http:// www.unesco.org/education/pdf/RIO_E.PDF.>. This principle has already been used by the Brazilian Supreme Court in order to justify the national policy regarding the import of used tyres. The application is somewhat erroneous, given that there is little scientific uncertainty over the toxic residues from tyres and the difficulty of safely discarding them. Nonetheless, it is an interesting decision to see how the principle is being applied worldwide. See more at BORGES, D. D. O princípio do desenvolvimento sustentável no direito internacional público. In: MANIGLIA, E. (Org.). 50 anos do Estatuto da Terra: 25 anos de Direito Agrário na UNESP. São Paulo: Cultura Acadêmica, 2014. p. 179-196.

23 LENNON, G. Precautionary tales: suspicionless counter-terrorism stop and search. Criminology \& Criminal Justice, v. 15, n. 1, p. 44-62, 2013. p. 45-46. Available on: <https://doi.org/10.1177/174 8895813509637.>.

24 STERN, J.; WIENER, J. Precaution against terrorism. Journal of Risk Research, v. 9, n. 4, p. 393-447, 2006. p. 397-398. Available on: <https://www.belfercenter.org/sites/default/files/legacy/files/ Precaution\%20Against $\% 20$ Terrorism.pdf $>$. 
members, locations and weaponry are unknown"25.

Nevertheless, there is a profound difference between the precautionary measures adopted for environment regulation, mainly financial burdens over businesses and government, whereas on counter-terrorism regulation, the potential impacts are upon human rights, impacting people directly. The precautionary measures to counter terrorist attacks involve a temporal shift in the focus of traditional criminal law, changing from a "post-crime" to a "pre-crime" approach. The "pre-crime" approach means that instead of investigating, trying and punishing individuals prompt by the occurrence of crimes, it will be possible to take coercive actions against people "who are believed will commit an offence in the future but have not done so yet", exactly in the opposite direction that criminal justice traditionally runs ${ }^{26}$, presenting the potential dangers of this method on the protection of human rights.

Therefore, to further illustrate our proposed theory, there follows an arrow diagram aiming to provide a visual comprehension:

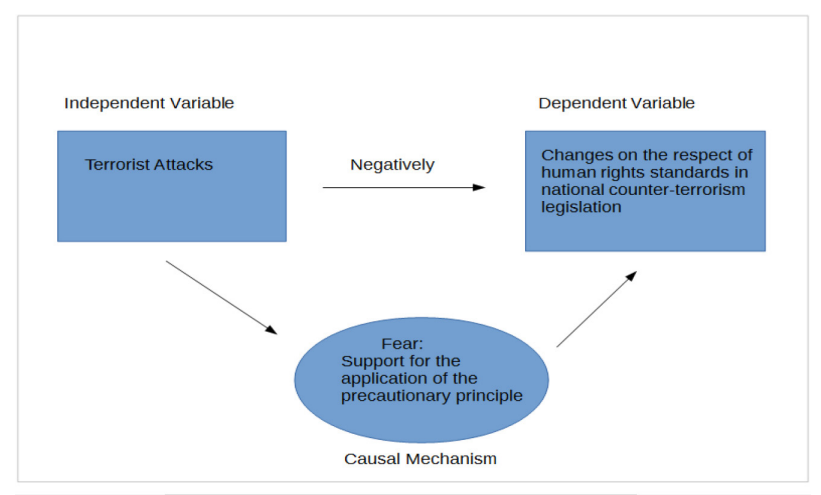

Our hypotheses, therefore, reflect the pursue to understand the causal mechanism between terrorist attacks and counter-terrorism measures less protective of human rights, and we ought to do it through a process-tracing analysis, which means going step by step through the aspects that, if correct, will unveil how an intense sense of fear, risen because of acts of terrorism, affected the following counter-terrorism legislation.

Thus, the hypotheses that will be analyzed in this

25 STERN, J.; WIENER, J. Precaution against terrorism. Journal of Risk Research, v. 9, n. 4, p. 393-447, 2006. p. 397-398. Available on: <https://www.belfercenter.org/sites/default/files/legacy/files/ Precaution\%20Against\%20Terrorism.pdf $>$.

26 LENNON, G. Precautionary tales: suspicionless counter-terrorism stop and search. Criminology \& Criminal Justice, v. 15, n. 1, p. 44-62, 2013. p. 45-46. Available on: <https://doi.org/10.1177/174 8895813509637.>. study are:

Hypothesis 1: if terrorist attacks lead to an intense sensation of fear, there should be evidence of greater fear among people after a given attack.

Hypothesis 2: if fear leads to support for the application of the precautionary principle, there should be evidence of this support among citizens' public opinion.

Hypothesis 3: if the precautionary principle leads to counter-terrorism laws that are less protective of buman rights standards, there should be evidence of this type of change in counter-terrorism legislation.

\section{Research Design}

This research will be conducted upon one single case, the United States (hereafter US), before and after 9/11. The decision to conduct the study on the US response to these specific terrorist attacks involves the country's prominent influence on international politics and is based on scholars understanding that countries which are more likely to be politically pressured by western countries, or that maintain close relations with them, often lead to the adoption of more repressive policies ${ }^{27}$. Shor et al. corroborates this with their research results that show support for the claims in which governments that keep relevant political and economic relations with the US and are dependent of its aid, this "tend to have deleterious effects in terms of countries' respect for human rights" ${ }^{28}$. Thus, analyzing any other case would possibly be a country that was influenced by US anyhow, being hard to isolate such a variable. Also, analyzing a country that does not have close relations with US would, possibly lead to a non-democratic country, which is also a control variable that we deem of significant importan-

27 See generally CHOMSKY, N. The culture of terrorism. Boston: South End Press, 1988.; CHOMSKY, N. International terrorism: image and reality. In: GEORGE, A. (Ed.). Western state terrorism. New York: Routledge, 1991. p. 12-38.; GEORGE, A. Introduction. In: GEORGE, A. (Ed.). Western state terrorism. New York: Routledge, 1991. p. 1-11.; GILL, L. The school of the Americas: military training and political violence in the Americas. Durham: Duke University Press, 2004.; LUSTICK, I. S. Trapped in the War on Terror. Philadelphia: University of Pennsylvania Press, 2006.; SIKKINK, K. Mixed signals: U.S. human rights policy and Latin America. Ithaca: Cornell University Press, 2004.

28 SHOR, et al. Terrorism and state repression of human rights: a cross-national time-series analysis. International Journal of Comparative Sociology, v. 55, n. 4, p. 305, 2014. 
ce, once we assume that a non-democratic country is less likely to maintain high human rights standards.

The choice was also made upon the fact that although US is a signatory state of, surprisingly, quite a few human rights treaties until May of $2016^{29}$, its Constitutions is one of the firsts concerned with the defense of human rights. The Bill of Rights annexed to the Constitution a couple of years later, 1791, included several protections to the person accused of crime as "speedy and public trial, information as to the nature and cause of accusation", also "prohibition of the suspension of the writ of habeas corpus and prohibition of ex post facto laws" "30, some of the rights that will be investigated in this study and that US has protected almost from its origin. One could say that these principles are deeply rooted in the country's foundations.

Regarding the choice of terrorist attack, we chose September 11 for several reasons. First, although US had previously experienced terrorist attacks, they had never caused this much casualties, almost 3.000 deaths $^{31}$. Second, because the attacks, according to a poll conducted by Zogby International in 2007 showed that, even after 6 years of the attacks, $81 \%$ of those interviewed either "strongly agreed" or "somewhat agreed" that the events of 9/11 permanently altered how Americans "view the world" 32 . Third, because we agree with what Howie argues, that other terrorist attacks that followed $9 / 11$, like $7 / 7$ of London, may seem less important not only because there were fewer casualties and destruction, but also because, as the author suggests, 9/11 had "real-time, powerful and terrifying images", allowing people from different space and time situations to witness what was occurring ${ }^{33}$. One of the authors, only a kid at the time, remembers watching on

29 UNHR. Status of Ratification Interactive Dashboard. Ratification of 18 International Human Rights Treaties. United Nations Human Rights: Office of the High Commissioner. Available on: <http:// indicators.ohchr.org/>.

30 DOWLING, N. T. Protection of human rights under the United States Constitution. The Annals of the American Academy of Political and Social Science, v. 243, p. 96-100, 1946. p. 96-97. Available on: <http://www.jstor.org/stable/1025061>.

31 STATISTIC BRAIN. 9/11 death statistics. Statistic Brain, nov. 2015. Available on: <https://www.statisticbrain.com/911-deathstatistics $/>$.

32 SHANTY, F. Impact of 9/11 on U.S. public opinion. In: GOLDMAN, J. (Ed.). The War on Terror Encyclopedia: from the rise of Al Qaeda to 9/11 and beyond. ABC-CLIO; LLC, 2014. p. 180.

33 HOWIE, L. Terrorism, the worker and the city. Farnham: Gower, 2012. p. 5 . the news, over and over, the crash of the airplanes and the fall of the twin towers, to the point that she believes it is rather unlikely that, whenever thinking about terrorist attacks, 9/11 would not appear as the first image. Although other terrorist acts of violence also produce terrifying images and consequences, Howie argues that they are all "part of a post9/11 theatre of terrorism", and perhaps, in most parts of the world, evoke the memories of $9 / 11^{34}$. To sum up, we assume that the events of September 11 changed the way people in general, but specially US citizens, perceive terrorism.

Regarding the method of analysis more suited to conduct this study, initially, we imagined that doing an across-case analysis using structured focused comparison would be rather interesting, because we could take a country that had terrorist attacks and a country that did not have and compare them, however, when accessing terrorist attacks databases, we could not find a country that we had linguistic knowledge to assess its legislation and had no historic of terrorist attacks. Of course, the consideration of an attack as terrorist depends on the definition used by the dataset, and comparing theirs with ours, perhaps we would not have considered them as such. However, even if we do not consider events like bombings with no claimed authorship, or manifestations that seem more like genuine struggles than like terrorist attacks, it does not change that fact that national authorities and the media could have perceived them as so, possibly influencing the country's population and legislative decisions anyways. Therefore, given this difficulty to find cases where there was no occurrence of terrorist attacks, we decided to do a within-case analysis, through the evaluation of a country's counter-terrorism legislation before and after a terrorist attack.

The choice of method of analysis was also guided by our ambition to understand and possibly explain the full process through which the causal mechanism develops itself in this particular case. We do not aim only to explain how terrorist acts of violence possibly affect counter-terrorism legislation, but also to break down the steps between one and another, if, in fact, they are connected. As explained by Bennett and Checkel, the process-tracing method aims "the examination of the intermediate steps in a process to make inferences about hypotheses on how that process took place and

34 HOWIE, L. Terrorism, the worker and the city. Farnham: Gower, 2012. p. 5 . 
whether and how it generated the outcome of interest"; it uses the available sources "to see whether the causal process a theory hypothesizes or implies in a case is in fact evident in the sequence and values of the intervening variables in that case" ${ }^{\prime 3}$.

Hence, we have broken down the possible connection between the independent and dependent variables in three hypotheses, so that only if all of them hold the proposed theory would also holds. The first hypothesis is about the terrorist acts of violence and its consequential fear. We intend to infer this causation through public opinion polls conducted in US after the attacks of September 11 that assess the general levels of fear. The second hypothesis reasons upon the US citizens support for the application of the precautionary principle in the country's policy, and we believe it is possible to assess this also by public opinion polls regarding some indicators like governmental access to private information, due process, preventive detention, torture and coercive questioning, if possible, prior to the actual moment of taking any measures. Through the third hypothesis, we expect that the application of the precautionary principle, assuming that the second hypothesis was confirmed, will result in changes on counter-terrorism legislation that, previously, did not but, after the terrorist violence, includes measures that violate human rights standards that US was legally committed to protect.

Regarding the operationalization of the variables involved in this research, with the aim of proving our theory, it will be done as follows. The independent variable is the "occurrence of terrorist attacks", and, for the specific case chosen to this study the measure to this variable will be a yes or no question, also analyzing why, according to the definition of terrorism adopted in this research, the chosen act of violence is considered as a terrorist attack. The dependent variable is the "possible change in counter-terrorism legislation regarding its respect of human rights standards", and it will be assessed by the analysis of counter-terrorism legislation from before and after the occurrence of the chosen terrorist attack, specifically the "Anti-terrorism and Effective Death Penalty Act of 1996", and the "USA Patriot Act of 2001". This legislation will be compared through a set of indicators that follows: access to private information;

35 BENNETT, A.; CHECKEL, J. T. Process tracing: from metaphor to analytic tool. Cambridge: Cambridge University Press, 2015. p. 6. due process; preventive detention; torture and coercive questioning. We expect these factors to be the most relevant ones to suffer alterations because we assume that US society, as the country with the highest incarcerated population of the world ${ }^{36}$, almost twice the numbers of China, the second in the ranking, to be more prone to try to solve and deal with the new threats increasing detentions and other measures that surround it. The intervening variable, also named as causal mechanism in this study, is the population's fear caused by the terrorist attack. We believe that this fear is expressed as support for the application of the precautionary principle on the measures that the executive and legislative propose and adopt. Therefore, this variable will be operationalized through the observance of public opinion polls regarding the adoption of repressive measures including the indicators previously mentioned.

One may wonder, "why legislation should matter?", and we should say that the choice to analyze the possible effects of terrorist acts of violence on legislation was based in the presumption that democratic countries take their legislation seriously. In addition, because researchers like Fitzpatrick ${ }^{37}$ have found that legislation, in general made to assist countries in the fight against terrorism and secure the safety of their citizens, came at the expense of the respect of human rights standards even in liberal democracies, taken as a zero-sum game. One may also wonder, "why the 'Anti-terrorism and Effective Death Penalty Act of 1996' and the 'Patriot Act of 2001'?", and, as previously mentioned, the chosen terrorist attack is $9 / 11$, so, the legislation chosen from before these attacks is the 1996 Act, which the proper name raises some questions upon its human rights standards, however, as debatable as death penalty is, it is a measure federally not prohibited and adopted in several states in US, existent before the 9/11 attacks. Therefore, this Act was chosen because it included the latest "state of the art" before the events. The legislation to be compared is the Patriot Act, which became public law on the $26^{\text {th }}$ of October of 2001, exactly forty-six days after the attacks. We believe that these were the in-between days of most terror and fear on most of

36 WPB. Highest to lowest: prison population total. World Prison Brief. Institute for Criminal Policy Research. Available on: < http:// www.prisonstudies.org/highest-to-lowest/prison-populationtotal?field_region_taxonomy_tid $=$ All $>$.

37 FITZPATRICK, J. Speaking law to power: the war against terrorism and human rights. European Journal of International Law, v. 14, n. 2, apr. 2003. 
the world and, specially, on US citizens, which we expect to have greatly influenced the content of this law.

An important aspect of the process-tracing method involves casting the net widely for alternative explanations, which means to "assess the process-tracing evidence" of a wide range of proposed alternative explanations for my specific case. Therefore, "failing to consider a potentially viable explanation that readily occurs to the readers and critics of a case study can make the process tracing unconvincing" ${ }^{38}$.

This study will consider and apply the process tracing method also on the following two alternative explanations brought up by Shor et al. ${ }^{39}$ and Roger Douglas ${ }^{40}$. The theory proposed by Shor et al. is that "states choose to react to terrorism with repressive measures because they believe this is the best way to stop or at least reduce these attacks, but also in order to win the support of their local constituency and guard against oppositional forces" ${ }^{41}$. What their study expect is that unpopular and unstable governments will react more repressively to terrorist attacks. In addition, their approach expects that domestic pressure created by involvement in wars, international disputes or political pressure may, as well, increase repression. Therefore, "countries involved in violent disputes (whether international or domestic) and those suffering from political instability and unrest will be more likely to adopt repressive policies" ${ }^{\prime 2}$. We do believe that these factors may have significant impact to the specific case of US, therefore we intend to assess their possible influence through a brief presentation of the US situation just before the terrorist attacks of 9/11, and the public support for George W. Bush through public opinion polls.

In turn, the alternative explanation proposed by Roger Douglas suggests, as previously mentioned, that situations like the $9 / 11$ terrorist attacks present itself

38 BENNETT, A.; CHECKEL, J. T. Process tracing: from metaphor to analytic tool. Cambridge: Cambridge University Press, 2015. p. 23.

39 SHOR, et al. Terrorism and state repression of human rights: a cross-national time-series analysis. International Journal of Comparative Sociology, v. 55, n. 4, 2014.

40 DOUGLAS, R. Law, liberty, and the pursuit of terrorism. Ann Arbor: The University of Michigan Press, 2014.

41 SHOR, et al. Terrorism and state repression of human rights: a cross-national time-series analysis. International Journal of Comparative Sociology, v. 55, n. 4, 2014. p. 298.

42 SHOR, et al. Terrorism and state repression of human rights: a cross-national time-series analysis. International Journal of Comparative Sociology, v. 55, n. 4, 2014. p. 298. as opportunities for the executive to take measures and to be seen as "doing something" for the protection of the population. Furthermore, that these moments can also be perceived by the executive and legislative as opportunistic situations to introduce measures that would otherwise be politically unacceptable ${ }^{43}$. Therefore, we intend to process-trace the Patriot Act creation and adoption in order to evaluate its possible "opportunism".

As presented so far, the empirical material that will be used involves a series of different sources, and there is the need for some source criticism beforehand. Regarding the measurement of the independent variable, the occurrence of terrorist attacks, September 11, although surrounded by several conspiracy theories ${ }^{44}$, is widely recognized by the international and national communities as a terrorist act of violence, hence that is what we will adopt. However, we would just like to note that if any of these theories were, in fact, right, it would change completely the understandings on terrorism and what measures should be taken. Considering the operationalization of the dependent variable, it involves the operationalization of the whole causal mechanism, traced through the three proposed hypotheses. The empirical material to be collected to the first two hypotheses, measurement of levels of fear on the population right after 9/11 and of population's support for the application of the precautionary principle consist in public opinion polls. Polls of public opinion are complex sources, once it is not always clear what the interests behind the involved companies are, also, the wording of the questions and possible introduced bias can greatly affect the results, following the inclinations of the survey. Therefore, what we intend to do is to triangulate different sources of polls that have, as much as possible, the same thematic approach to try to lessen the possible impacts that these shortcomings might have on this research. In turn, the third hypothesis does not have these problems once it is a primary source, meaning that we can analyze it without the interference of the interpretation of anyone else. However, we also must note that, in spite of our efforts to remain as impartial as possible,

43 DOUGLAS, R. Law, liberty, and the pursuit of terrorism. Ann Arbor: The University of Michigan Press, 2014. p. 1-2.

44 JAMES, B. 9/11 Conspiracy theories: inside the lonely lives of truthers, still looking for their big break. International Business Times, sep. 2015. Available on: <http://www.ibtimes.com/911-conspiracy-theories-inside-lonely-lives-truthers-still-looking-their-bigbreak-2091474>. 
our interpretations of the possible changes on counter-terror legislation will be affected by our background knowledge and understandings on these subjects. That is why we intend to be as clear and transparent as possible on the assumptions involved in this study so that you, our reader, can critically assess the results obtained and how they might have been affected by us.

Just before continuing to the section of this research where we will present the results found empirically, we wish to further illustrate the results that were expected beforehand, when we developed the theory, through the following tables for each hypothesis:

Hypothesis 1: if terrorist attacks lead to an intense sensation of fear, there should be evidence of greater fear among people after a given attack.

\begin{tabular}{|l|l|}
\hline Terrorist attack & Levels of fear \\
\hline $\mathbf{9 / 1 1}$ & High levels of sensation of fear \\
\hline
\end{tabular}

Hypothesis 2: if fear leads to support for the application of the precautionary principle, there should be evidence of this support among citizens' public opinion.

\begin{tabular}{|l|l|l|l|l|}
\hline Indicators & $\begin{array}{l}\text { Access } \\
\text { to private } \\
\text { informa- } \\
\text { tion }\end{array}$ & $\begin{array}{l}\text { Due Pro- } \\
\text { cess }\end{array}$ & $\begin{array}{l}\text { Preventive } \\
\text { Detention }\end{array}$ & $\begin{array}{l}\text { Torture } \\
\text { and Coer- } \\
\text { cive Que- } \\
\text { stioning }\end{array}$ \\
\hline $\begin{array}{l}\text { Support/ } \\
\text { Non-sup- } \\
\text { port }\end{array}$ & $\begin{array}{l}\text { More than } \\
1 / 3 \text { of } \\
\text { support }\end{array}$ & $\begin{array}{l}\text { More than } \\
1 / 3 \text { of }\end{array}$ & $\begin{array}{l}\text { More than } \\
1 / 3 \text { of }\end{array}$ & $\begin{array}{l}\text { More than } \\
1 / 3 \text { of } \\
\text { support }\end{array}$ \\
\hline
\end{tabular}

Hypothesis 3: if the precautionary principle leads to counter-terrorism laws that are less protective of human rights standards, there should be evidence of this type of change in counter-terrorism legislation.

\begin{tabular}{|c|c|c|c|c|}
\hline $\begin{array}{l}\text { Legisla- } \\
\text { tion/Indi- } \\
\text { cators }\end{array}$ & $\begin{array}{l}\text { Access } \\
\text { to private } \\
\text { informa- } \\
\text { tion }\end{array}$ & $\begin{array}{l}\text { Due Pro- } \\
\text { cess }\end{array}$ & $\begin{array}{l}\text { Preventive } \\
\text { Detention }\end{array}$ & $\begin{array}{l}\text { Torture } \\
\text { and Coer- } \\
\text { cive Que- } \\
\text { stioning }\end{array}$ \\
\hline \begin{tabular}{|l|} 
Before \\
$9 / 11$ \\
Act of \\
1996
\end{tabular} & $\begin{array}{l}\text { Not } \\
\text { allowed }\end{array}$ & Present & $\begin{array}{l}\text { Not } \\
\text { present }\end{array}$ & $\begin{array}{l}\text { Not } \\
\text { present }\end{array}$ \\
\hline $\begin{array}{l}\text { After 9/11 } \\
\text { Act of } \\
2001\end{array}$ & Allowed & $\begin{array}{l}\text { Not } \\
\text { present }\end{array}$ & Present & Present \\
\hline
\end{tabular}

\section{Results and Analysis}

This section will present, primarily, the results found for the proposed theory, and will follow the given sequence: independent variable, dependent variable divided in the results found for each of the three proposed hypotheses. In the sequence, the results found on the alternative explanations will be presented. The analysis of the results and the interpretation that this study adopts will follow the same aforementioned structure, once it will be given connected to each of the results presented.

The empirical material to analyze the independent variable was collected from three different sources. First, the RAND Database of Worldwide Terrorism Incidents, a compilation of data from 1968 to 2009 that define terrorism "by the nature of the act, not by the identity of the perpetrators or the nature of the cause", adopting the following criteria: "violence or the threat of violence; calculated to create fear and alarm; intended to coerce certain actions; motive must include a political objective; generally directed against civilian targets; can be a group or an individual"45. This database considers the events of $9 / 11$ as terrorist attacks and divide them into three distinct incidents: in Washington, $\mathrm{DC}^{46}$; Shanksville ${ }^{47}$; New York $\mathrm{City}^{48}$; that together sum up to over 3.000 deaths.

Second, the Global Terrorism Database ${ }^{49}$, an open-source database that includes information on terrorist events from 1970 to 2014. Their definition of terrorism is "the threatened or actual use of illegal force and violence by a non-state actor to attain a political, economic, religious, or social goal through fear, coercion, or intimidation", with the following criteria: "the violent act was aimed at attaining a political, economic, religious, or social goal; the violent act included evidence of an

45 RAND. Database Scope. Database of Worldwide Terrorism Incidents (RDWTI). Available on: < https://www.rand.org/nsrd/projects/terrorism-incidents/about/definitions.html>.

46 RAND. Terrorism Incidents Database Search. Incident Detail: Sep 11, 2001. Washington, DC, United States. Al Qaeda. Database of Worldwide Terrorism Incidents (RDWTI). Available on: < http://smapp. rand.org/rwtid/incident_detail.php?id=7759>.

47 RAND. Terrorism Incidents Database Search. Incident Detail: Sep 11, 2001. Shanksville, United States. Al Qaeda. Database of Worldwide Terrorism Incidents (RDWTI). Available on: < http://smapp. rand.org/rwtid/incident_detail.php?id=7758>.

48 RAND. Terrorism Incidents Database Search. Incident Detail: Sep 11, 2001. New York City, United States. Al Qaeda. Database of Worldwide Terrorism Incidents (RDWTI). Available on: <http://smapp. rand.org/rwtid/incident_detail.php?id=7757>.

49 GTD. Using GTD. Data collection methodology: data collection and the definition of terrorism. Global Terrorism Database. Available on: < https://www.start.umd.edu/gtd/using-gtd/>. 
intention to coerce, intimidate, or convey some other message to a larger audience (or audiences) other than the immediate victims; and the violent act was outside the precepts of International Humanitarian Law" 50 . This database also considers the attacks of $9 / 11$ as terrorist acts of violence and categorizes them in four events: the crash in the North Tower of the World Trade Center ${ }^{51}$; the crash in the South Tower of the World Trade Center ${ }^{52}$; the Pentagon ${ }^{53}$; and the plane that crash-landed near Shanksville but had the US Congress as target ${ }^{54}$.

Third, the United States Department of State uses the definition provided by the "Title 22 of the United States Code, Section 2656f(d)", in which "the term terrorism means premeditated, politically motivated violence perpetrated against noncombatant targets by sub-national groups or clandestine agents, usually intended to influence an audience" 55 . The State Department produces annual reports on terrorism since the year of 2000 called "Patterns of Global Terrorism" until 2004, when it became "Country Reports on Terrorism". A brief evaluation of the report produced for the year of 2001 shows that $9 / 11$ is defined as the "worst international terrorist attack ever" ${ }^{\prime 56}$.

Therefore, to further illustrate the results obtained analyzing the independent variable there is the following table:

50 GTD. Using GTD. Data collection methodology: data collection and the definition of terrorism. Global Terrorism Database. Available on: < https://www.start.umd.edu/gtd/using-gtd/>.

51 GTD. GTD ID: 200109110004. When: 2001-09-11. Country: United States. Global Terrorism Database. Available on: <https://www.start.umd.edu/gtd/search/IncidentSummary. aspx?gtdid $=200109110004>$.

52 GTD. GTD ID: 200109110005. When: 2001-09-11. Country: United States. Global Terrorism Database. Available on: <https://www.start.umd.edu/gtd/search/IncidentSummary. aspx?gtdid=200109110005>.

53 GTD. GTD ID: 200109110006. When: 2001-09-11. Country: United States. Global Terrorism Database. Available on: $<$ https://www.start.umd.edu/gtd/search/IncidentSummary. aspx?gtdid=200109110006>.

54 GTD. GTD ID: 200109110007. When: 2001-09-11. Country: United States. Global Terrorism Database. Available on: <https://www.start.umd.edu/gtd/search/IncidentSummary. aspx?gtdid $=200109110007>$.

55 UNITED STATES OF AMERICA. Patterns of Global Terrorism 2003. United States Department of State, 2004. p. 12. Available on: $<$ https://www.state.gov/documents/organization/31932.pdf>.

56 UNITED STATES OF AMERICA. Patterns of Global Terrorism 2001. United States Department of State, 2002. p. 1. Available on: $<$ https://www.state.gov/documents/organization/10319.pdf >.

\begin{tabular}{|l|l|}
\hline Sources & Results \\
\hline RAND & Terrorist Attacks \\
\hline GTD & Terrorist Attacks \\
\hline US State Department & Terrorist Attacks \\
\hline
\end{tabular}

We believe there is no need to further discuss the independent variable, except to stress that the events of 9/11 are well accepted as terrorist attacks, although, as previously mentioned, not unquestionably. We would like just to make a note before the next results to explain the choice of US State Department as a source. This choice was just to make clear that the US government as a whole also considered the $9 / 11$ events as terrorist attacks, which is important because it shows its interpretation of these incidents and how its institutions enunciated them to its citizens and world. Through these results, this study aims to have provided a solid ground for the subsequent presentation of its actual outcomes.

In the sequence, the results found for the independent variable will be presented divided by the proposed hypotheses.

Hypothesis 1: if terrorist attacks lead to an intense sensation of fear, there should be evidence of greater fear among people after a given attack.

\begin{tabular}{|l|l|l|l|}
\hline Question & Date & Result & Source \\
\hline $\begin{array}{l}\text { How worried } \\
\text { are you that } \\
\text { you or some- } \\
\text { one in your } \\
\text { family will be- } \\
\text { come a victim } \\
\text { of terrorism? }\end{array}$ & 2000 April 7-9 & $\begin{array}{l}\text { Very/so- } \\
\text { mewhat worri- } \\
\text { ed: } 24 \%\end{array}$ & Gallup $^{1}$ \\
\hline $\begin{array}{l}\text { How worried } \\
\text { are you that } \\
\text { you or some- } \\
\text { one in your } \\
\text { family will be- } \\
\text { come a victim } \\
\text { of terrorism? }\end{array}$ & 2001 Septem- & $\begin{array}{l}\text { Very/so- } \\
\text { mewhat worri- } 11\end{array}$ & Gallup ${ }^{2}$ \\
\hline $\begin{array}{l}\text { How worried } \\
\text { are you that } \\
\text { you or some- } \\
\text { one in your } \\
\text { family will be- } \\
\text { come a victim } \\
\text { of terrorism? }\end{array}$ & $11-14$ & ed: & \\
\hline
\end{tabular}




$\begin{aligned} & \text { How worried } \\ & \text { are you that } \\ & \text { another terro- }\end{aligned}$
$\begin{aligned} & \text { rist attack will } \\ & \text { happen soon? }\end{aligned}$

All these polls where conducted with Americans living in US, and the results were collected and presented here from different dates, initiating before the attacks, on the exact day, and on the period after them, to give a sense of how the levels of fear evolved. It shows the usual levels of fear previous to $9 / 11$ and how people reported to be affected by this terrorist incident. What can be inferred from these empirical materials is that the usual levels of fear from terrorism were not as significant as after the attacks, and that the high levels of fear perpetuated through the time. Although the numbers from Pew Research Center ${ }^{57}$ are significantly higher from Gallup ${ }^{58}$, we believe that both numbers show the existence of great distress among American citizens and, therefore, corroborate and support my proposed hypothesis that the occurrence of terrorist attacks would influence the levels of fear of a given population, increasing its perceptions of danger.

Hypothesis 2: if fear leads to support for the application of the precautionary principle, there should be evidence of this support among citizens' public opinion.

The empirical data collected for this hypothesis will be limited by the indicators that were previously men-

57 PEW RESEARCH CENTER. Americans open to dissenting views on the War on Terrorism. Pew Research Center. October 4, 2001. Available on: <http://www.people-press.org/2001/10/04/americansopen-to-dissenting-views-on-the-war-on-terrorism/ $>$.

58 GALLUP. Terrorism in the United States. Gallup. Available on: <http://www.gallup.com/poll/4909/terrorism-united-states. $\operatorname{aspx}>$. tioned, access to private information, due process, preventive detention, and torture, once my theory proposes that public support for the application of the precautionary principle in these areas will lead to its actual enactment, which will be further discussed on Hypothesis 3.

\begin{tabular}{|c|c|c|c|}
\hline $\begin{array}{l}\text { Indicator/Que- } \\
\text { stion }\end{array}$ & Date & Result & Source \\
\hline $\begin{array}{l}\text { Assassinate known } \\
\text { terrorists }^{5}\end{array}$ & $\begin{array}{l}2001 \text { October } \\
5-6\end{array}$ & Willing: $77 \%$ & Gallup $^{6}$ \\
\hline $\begin{array}{l}\text { Assassinate leaders } \\
\text { of countries that } \\
\text { harbor terrorists }^{7}\end{array}$ & $\begin{array}{l}2001 \text { October } \\
5-6\end{array}$ & Willing: $52 \%$ & Gallup ${ }^{8}$ \\
\hline $\begin{array}{l}\text { Torture known } \\
\text { terrorists if they } \\
\text { know details about } \\
\text { future terrorist } \\
\text { attacks in the U.S. }\end{array}$ & $\begin{array}{l}2001 \text { October } \\
5-6\end{array}$ & Willing: 45\% & Gallup $^{10}$ \\
\hline $\begin{array}{l}\text { Sacrifice Civil } \\
\text { Liberties to Curb } \\
\text { Terrorism. }\end{array}$ & $\begin{array}{l}2001 \text { Septem- } \\
\text { ber 13-17 }\end{array}$ & Yes: $55 \%$ & $\begin{array}{l}\text { Pew Research } \\
\text { Center }\end{array}$ \\
\hline National ID cards & $\begin{array}{l}2001 \text { Septem- } \\
\text { ber 13-17 }\end{array}$ & Favor: $70 \%$ & $\begin{array}{l}\text { Pew Research } \\
\text { Center }\end{array}$ \\
\hline CIA assassinations & $\begin{array}{l}2001 \text { Septem- } \\
\text { ber } 13-17\end{array}$ & Favor: $67 \%$ & $\begin{array}{l}\text { Pew Research } \\
\text { Center }\end{array}$ \\
\hline $\begin{array}{l}\text { Monitor credit } \\
\text { cards }\end{array}$ & $\begin{array}{l}2001 \text { Septem- } \\
\text { ber } 13-17\end{array}$ & Favor: $40 \%$ & $\begin{array}{l}\text { Pew Research } \\
\text { Center }\end{array}$ \\
\hline Internment camps & $\begin{array}{l}2001 \text { Septem- } \\
\text { ber 13-17 }\end{array}$ & Favor: $29 \%$ & $\begin{array}{l}\text { Pew Research } \\
\text { Center }\end{array}$ \\
\hline $\begin{array}{l}\text { Monitor phone/ } \\
\text { email }\end{array}$ & $\begin{array}{l}2001 \text { Septem- } \\
\text { ber 13-17 }\end{array}$ & Favor: $26 \%$ & $\begin{array}{l}\text { Pew Research } \\
\text { Center }\end{array}$ \\
\hline
\end{tabular}

5 The question asked for this indicator was "Would you be willing -- or not willing -- to have the U.S. government do each of the following, if the government thought it were necessary to combat terrorism? How about -- [RANDOM ORDER]?".

6 GALLUP. War on terrorism. Gallup. Available on: <http://www.gallup.com/poll/5257/War-terrorism. aspx?g_source $=$ terrorism $\% 202001 \& g_{\text {_ }}$ medium $=$ search $\& g_{-}$ campaign $=$ tiles $>$.

7 The question asked for this indicator was "Would you be willing -- or not willing -- to have the U.S. government do each of the following, if the government thought it were necessary to combat terrorism? How about -- [RANDOM ORDER]?”.

8 GALLUP. War on terrorism. Gallup. Available on: <http://www.gallup.com/poll/5257/War-terrorism. aspx?g_source $=$ terroris $\%$ \%202001\&g_medium $=$ search\&g_ campaign $=$ tiles $>$.

9 The question asked for this indicator was "Would you be willing -- or not willing -- to have the U.S. government do each of the following, if the government thought it were necessary to combat terrorism? How about -- [RANDOM ORDER]?".

10 GALLUP. War on terrorism. Gallup. Available on: < http://www. gallup.com/poll $/ 5257 /$ War-terrorism.aspx?g_source $=$ terrorism $\% 20$ 2001\&g_medium $=$ search\&g_campaign=tiles $>$. 
These are the polls we could find from before the enactment of the Patriot Act, this decision upon the collection of data relies on a common understanding that laws may alter people's perception of what is right or wrong, therefore, we believe that what appears on them beforehand will be reflected on the content of the Patriot Act. These polls reveal some intriguing data, once both the Gallup ${ }^{59}$ and the Pew Research Center ${ }^{60}$ polls showed strong support for the assassination of terrorists. It does not say "death penalty if convicted through a due process, with proper chances of defense", but assassination directly. It is our understanding that this reflects what Hahn and Sunstein ${ }^{61}$ question regarding the pursuit of a "risk free" environment, "how safe is safe enough?", and it appears that Americans were willing to support measures that would not follow the due process of law, at least regarding suspected terrorists, given that these individuals are mere suspects until convicted or absolved. We do not expect to find legal measures that make these types of assassinations legal on the Patriot Act, once this would attract great international and national attention, however, we do expect it to reflect as relaxation of the due process, providing less opportunity of defense to individuals accused of terrorism.

Regarding torture, its support is not as strong as for assassinations, nonetheless, $45 \%$ of the questioned population would be willing that the government conducted torture procedures on terrorists that had information on terrorist attacks. If one can claim that these polls are indeed generalizable, then, we believe that $45 \%$ of US population is significant enough to endorse this type of measure. Therefore, we also expect to find relaxation of the methods of interrogation on the Patriot Act.

The access to private information have mixed results according to the polls, once Americans seem to agree that it is necessary to sacrifice civil liberties in order to

59 GALLUP. War on terrorism. Gallup. Available on: <http: / / www.gallup.com/poll/5257/War-terrorism. aspx?g_source $=$ terrorism $\% 202001 \&$ g_medium $=$ search \&g_ campaign $=$ tiles $>$.

60 PEW RESEARCH CENTER. American psyche reeling from terror attacks. Pew Research Center. September 19, 2001. Available on: <http://www.people-press.org/2001/09/19/other-importantfindings-and-analyses-48/>.

61 HAHN, R. W.; SUNSTAIN, C. R. The precautionary principle as a basis for decision making. The Economists' Voice, v. 2, n. 2, article $8,2005$. curb terrorist activity. However, when further inquired about which specific rights could be sacrificed in order to halt terrorism national ID cards were highly supported $(70 \%)$ and monitoring credit cards also had considerable support (40\%), but internment camps for legal immigrants from hostile nations, like the Japanese camps on US during World War II, and monitoring phone/email conversations without legal injunction were strongly opposed, both with less than one-third of population's support. From these results we assume that Americans in general were not so prone to believe that more intrusive regulatory measures would lead to greater safety, and finding this type of legal prescription on the legislation will require further research to explain.

Concluding, we could not find any polls from before the enactment of the Patriot Act about Americans opinion on torture, therefore, without this data we cannot apply our theory to this indicator, regardless of finding it or not on the counter-terrorism legislation.

Hypothesis 3: if the precautionary principle leads to counter-terrorism laws that are less protective of human rights standards, there should be evidence of this type of change in counter-terrorism legislation.

The results found for this hypothesis will be presented as follows. First a table with both the empirical data collected from the "Anti-terrorism and Effective Death Penalty Act of 1996" and the "Patriot Act of 2001" divided by the proposed indicators and their evaluation. In the sequence, the discussion upon the possible implications and interpretations of the empirical results.

\begin{tabular}{|l|l|l|l|l|}
\hline $\begin{array}{l}\text { Legisla- } \\
\text { tion/Indi- } \\
\text { cators }\end{array}$ & $\begin{array}{l}\text { Access } \\
\text { to private } \\
\text { informa- } \\
\text { tion }\end{array}$ & $\begin{array}{l}\text { Due Pro- } \\
\text { cess }\end{array}$ & $\begin{array}{l}\text { Preventive } \\
\text { Detention }\end{array}$ & $\begin{array}{l}\text { Torture } \\
\text { and Coer- } \\
\text { cive Que- } \\
\text { stioning }\end{array}$ \\
\hline $\begin{array}{l}\text { Before } \\
\mathbf{9 / 1 1}\end{array}$ & $\begin{array}{l}\text { Not allo- } \\
\text { wed }\end{array}$ & $\begin{array}{l}\text { Partially } \\
\text { Present }\end{array}$ & $\begin{array}{l}\text { Not pre- } \\
\text { sent }\end{array}$ & $\begin{array}{l}\text { Not pre- } \\
\text { sent }\end{array}$ \\
$\mathbf{1 9 9 6}$
\end{tabular}

\subsection{Access to private information}

In the Act of 1996, the Section 804, Requirement to Preserve Record Evidence, stipulates that "[a] provider 
of wire or electronic communication services or a remote computing service, upon the request of a governmental entity, shall take all necessary steps to preserve records and other evidence in its possession pending the issuance of a court order or other process", continuing indicating that the recorded evidence "shall be retained for a period of 90 days, which shall be extended for an additional 90-day period upon a renewed request by the governmental entity" ${ }^{62}$. At first, it might not seem problematic, nevertheless, on a deeper analysis, it does not say that a governmental entity may request the recording of any private conversation, however, it does say that if there is some record evidence, the governmental entity can require its preservation even in the absence of a court order, however, this type of decision, whether to record or to keep the recordings, should only be made by the judiciary.

Nonetheless, on the Section 810 the Attorney General is asked to submit a report to the Congress including "recommendations for the use of electronic devices in conducting surveillance of terrorist or other criminal organizations", and "a summary of instances in which Federal law enforcement authorities may have abused electronic surveillance powers and recommendations, if needed, for constitutional safe-guards relating to the use of such powers" "63. Although at Section 804 there is a procedural issue, it does not exactly constitute a violation of rights, and the Section 810 is clear that the surveillance should be done according to the law, not indicating anything that could lead to an understanding that this law was enlarging surveillance powers by doing it without juridical authorization.

The "Title II - Enhanced Surveillance Procedures" in the Patriot Act ${ }^{64}$ under Section 501 stress that in order to collect evidence to an investigation, the Director of the Federal Bureau of Investigation has to apply for an order that may be granted or not by a United States

62 ANTI-TERRORISM ACT. Anti-terrorism and Effective Death Penalty Act of 1996. Public Law 104-132. April 24, 1996. p. 94. Available on: <https://www.congress.gov/104/plaws/ publ132/PLAW-104publ132.pdf $>$.

63 ANTI-TERRORISM ACT. Anti-terrorism and Effective Death Penalty Act of 1996. Public Law 104-132. April 24, 1996. p. 99-100. Available on: <https://www.congress.gov/104/plaws/ publ132/PLAW-104publ132.pdf>.

64 PATRIOT ACT. Uniting and Strengthening America by Providing Appropriate Tools Required to Intercept and Obstruct Terrorism (USA PATRIOT ACT) Act of 2001. p. 7. Available on: $<$ https://www.gpo.gov/fdsys/pkg/BILLS-107hr3162enr/pdf/ BILLS-107hr3162enr.pdf $>$.
Magistrate Judge (2001, p. 16). The provisions of the Patriot Act, according to my understanding, preserve the dependence upon judicial approval of collecting evidence through surveillance, however, in the Section 203 , it authorizes information obtained in criminal investigations to be shared with intelligence agencies ${ }^{65}$, releasing private information to become data of these agencies. The legislation that we discovered to contain the most invasive measures still in practice is the Foreign Intelligence Surveillance Act of 1978 (FISA), through which "the president, through the attorney general, is permitted to authorize surveillance and searches without the need for a court order, but only if there is little likelihood that this will affect a US person" "However, as the FISA legislation is from 1978, several years before the 9/11 terrorist acts of violence, this study's theory cannot be applied to it.

\subsection{Due Process}

Under the Title IV of the Act of 1996, criminal procedural involves mainly the prosecution of aliens alleged as terrorists, and the removal hearing seems to follow all the necessary legal requirements to give proper opportunity of defense and the Judge has to decide only upon the evidence introduced at this hearing ${ }^{67}$. However, there is a dangerous provision denying the access of classified information to the defense when its disclosure is considered to present a risk to national security, and an alien can be convicted as terrorist and expelled from the country based solely on this type of information, from which the alien cannot properly defend ${ }^{68}$. Therefore, it is my understanding that this breach compromises the due process and its application is dangerously convenient. Hence, we would argue that there is some compromise of the due process in this

65 PATRIOT ACT. Uniting and Strengthening America by Providing Appropriate Tools Required to Intercept and Obstruct Terrorism (USA PATRIOT ACT) Act of 2001. p. 10. Available on: <https://www.gpo.gov/fdsys/pkg/BILLS-107hr3162enr/pdf/ BILLS-107hr3162enr.pdf > .

66 DOUGLAS, R. Law, liberty, and the pursuit of terrorism. Ann Arbor: The University of Michigan Press, 2014. p. 69.

67 ANTI-TERRORISM ACT. Anti-terrorism and Effective Death Penalty Act of 1996. Public Law 104-132. April 24, 1996. p. 48-49. Available on: <https://www.congress.gov/104/plaws/ publ132/PLAW-104publ132.pdf $>$.

68 ANTI-TERRORISM ACT. Anti-terrorism and Effective Death Penalty Act of 1996. Public Law 104-132. April 24, 1996. p. 50. Available on: <https://www.congress.gov/104/plaws/ publ132/PLAW-104publ132.pdf $>$. 
specific provision, but that, in general, the rest of the procedure is respective of due process rights.

The Patriot Act presents that "a court may admit evidence that is otherwise inadmissible under the Federal Rules of Evidence, if the court determines that the evidence is reliable, and that compliance with the Federal Rules of Evidence may jeopardize the national security interests of the United States" ${ }^{69}$, which clearly is a relaxation of the due process, opening the opportunity to use evidence collected illegally, like wiretapping done without court order, or even collected by torturing suspects. Regarding the use of secret evidence, there is no specific provision in the Patriot Act, however, it is known to have been applied also after $9 / 11^{70}$.

\subsection{Preventive Detention}

There was no mention of this type of measure in the Act of 1996, not with the terms "preventive detention", "administrative detention", "temporary custody", or any variations from these combinations. The provisions involving detention and custody were solely regarding post-conviction.

In the Patriot Act, however, the Section 412 refers to "Mandatory Detention of Suspected Terrorists", presenting that the Attorney General shall take custody of any alien that is engaged in any activity that endangers the national security of the country ${ }^{71}$. The Attorney General has no more than seven days after the beginning of the detention to charge the individual with a criminal offense otherwise, the alien shall be released ${ }^{72}$.

69 PATRIOT ACT. Uniting and Strengthening America by Providing Appropriate Tools Required to Intercept and Obstruct Terrorism (USA PATRIOT ACT) Act of 2001. p. 38. Available on: <https://www.gpo.gov/fdsys/pkg/BILLS-107hr3162enr/pdf/ BILLS-107hr3162enr.pdf $>$.

70 SECRET evidence in the War on Terror. Harvard Law Review, v. 118, n. 6, p. 1962-1984, 2005. Available on: <http://www.jstor.org. ezproxy.its.uu.se/stable/4093289>.

71 PATRIOT ACT. Uniting and Strengthening America by Providing Appropriate Tools Required to Intercept and Obstruct Terrorism (USA PATRIOT ACT) Act of 2001. p. 80. Available on: <https://www.gpo.gov/fdsys/pkg/BILLS-107hr3162enr/pdf/ BILLS-107hr3162enr.pdf $>$.

72 PATRIOT ACT. Uniting and Strengthening America by Providing Appropriate Tools Required to Intercept and Obstruct Terrorism (USA PATRIOT ACT) Act of 2001. p. 80. Available on: $<$ https://www.gpo.gov/fdsys/pkg/BILLS-107hr3162enr/pdf/ BILLS-107hr3162enr.pdf $>$.

\subsection{Torture and Coercive Questioning}

On the Act of 1996, there was no mention of the words and expressions "torture", "coercion", "coercive questioning", "coercive interrogation", or as the CIA and the military describe them, "enhanced interrogation techniques"73, except when referring to crimes, condemning this type of measure, therefore, nothing suggesting its possible use.

The same happened in the Patriot Act, which did not present any procedural measures about interrogation, but condemned practices like torture, including it in the Federal definition of terrorism ${ }^{74}$. Nonetheless, the reality is that torture techniques were used against suspects of terrorism at Guantanamo Bay and Abu Ghraib prisons $^{75}$, and the pictures revealed from these situations were a great scandal showing how US was treating its prisoners. Shor et al. actually argue that avoiding new legislation that violate human rights standards might be preferable by some countries, to avoid drawing attention to these measures and invite international criticism ${ }^{76}$.

To give a summarizing answer to my research question, according to my empirical results, there was medium support for the sacrifice of civil liberties and the Patriot Act introduced partial changes with the information-sharing between criminal cases and intelligence agencies. Considering the respect of due process, it was a highly attacked right by the polls, given the high support for extrajudicial killings. Due process actually faced a relaxation on its respect, once the Patriot Act allows the use of illegal evidence in court. Preventive detention will not be considered, because we could not access US citizens perception of it before the enactment of the Patriot Act, nonetheless, we did not find any mention of it in the Act of 1996, while on the Patriot Act it

73 GRONKE, et al. U.S. public opinion on torture: 2001-2009. Symposium: Terrorism and Human Rights, july 2010. DOI:10.1017/ S1049096510000697. p. 438.

74 PATRIOT ACT. Uniting and Strengthening America by Providing Appropriate Tools Required to Intercept and Obstruct Terrorism (USA PATRIOT ACT) Act of 2001. p. 107-108. Available on: <https://www.gpo.gov/fdsys/pkg/BILLS-107hr3162enr/pdf/ BILLS-107hr3162enr.pdf $>$.

75 WHITE, J. Abu Ghraib tactics were first used at Guantanamo. The Washington Post, july 14, 2005. Available on: <http:// www.washingtonpost.com/wp-dyn/content/article/2005/07/13/ AR2005071302380.html>.

76 SHOR, et al. Terrorism and state repression of human rights: a cross-national time-series analysis. International Journal of Comparative Sociology, v. 55, n. 4, 2014. p. 13. 
became a procedure. Torture, which also had medium support among US citizens, was not present in neither of the legislation.

Regarding the alternative explanations, Shor et al. defended that countries experiencing internal distress, with unstable and unpopular governments would be more likely to adopt repressive measures, however, the ratings from before the terrorist attacks show a strong support for George W. Bush before 9/11, hence, we cannot consider this a viable explanation for the measures adopted.

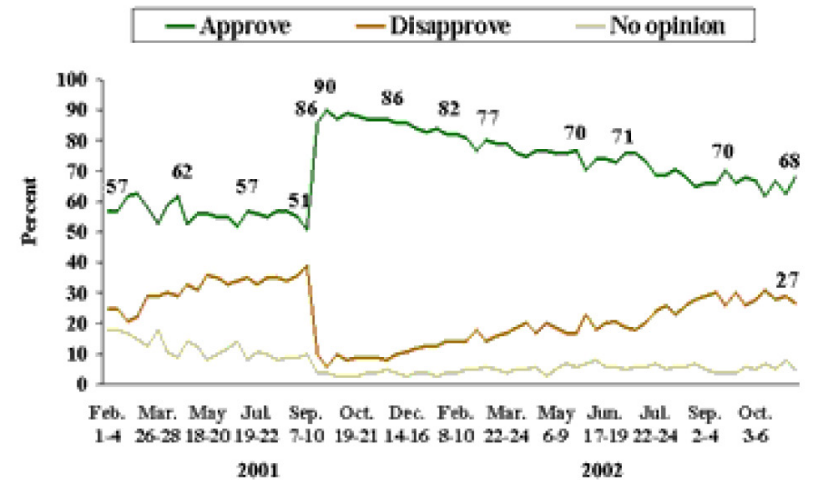

Source: Gallup ${ }^{77}$

One should explain that to properly process trace Roger Douglas alternative explanation it would be necessary a deeper previous knowledge on how the US political scenario develops and more time to analyze the political exchanges during the process of enactment of the counter-terrorism legislation that followed 9/11. However, what we could assess is that the content of the Patriot Act precedes the terrorist attacks, in other words, it was prepared before them. There was already a pursuit of more repressive measures among political representatives, and the terrible incidents of September 11 provided a rare opportunity to enlarge the government powers and reduce the civil liberties of American citizens $^{78}$.

Recapitulating the proposed theory for this study, it argues that terrorist attacks create an intense sense of fear in the population that, in turn, responds supporting

77 This graphic was retrieved from Gallup, Bush Approval at 68\%. by David W. Moore. November 15, 2002. Available at: <http:// www.gallup.com/poll/7222/bush-approval-68.aspx>.

78 CONN, T. L. Use of secret evidence by government lawyers: balancing defendants' rights with national security concerns. Cleveland State Law Review, 2004. p. 581. Available on: <http://engagedscholarship.csuohio.edu/cgi/viewcontent.cgi?article $=1297 \&$ contex $\mathrm{t}=$ clevstlrev $>$. repressive measures to counter terrorism. This study found that terrorist attacks really lead to an intense perception of danger and a consequent sensation of fear. The research also found that this fear led to a support of some of the proposed indicators, specifically, relaxation of due process, sacrifice of civil liberties in exchange of security, and torture, while there was no available data on the support or not for preventive detention. Finally, when accessing the legislation, there was clear further relaxation of due process rights, especially with the acceptance of illegal evidence, and this is the only indicator that this research can actually explain the changes, because it is the only one that follows the causation proposed by the theory. Therefore, our theory holds only for this indicator. The alternative theory from Douglas ${ }^{79}$ is not an excluding theory, once the opportunism of the Patriot Act is quite clear, especially with the information that its project preceded 9/11. Also, because it aims to explain the process of counter-terrorism legislation promulgation through the perspective of decision-makers, whilst we aimed to explain the process through the perspective of the country's population, because in a democratic country that upholds its sense of legality, legitimacy and respect of the law, without the support of its citizens, such changes would hardly be accepted.

This study, even though it was not found strong support for our theory, shows briefly that the fear populations experience because of acts of violence, especially terrorist attacks, does no good. The high support for the assassination of suspects of terrorism really surprised us. That is why we believe that campaigns like \#wearenotafraid, done in Indonesia after the Jackarta attacks should be propagated, helping to reduce the sensation of insecurity among citizens and to maintain them rational enough to calculate the costs and benefits from the measures proposed and not accept undue restrictions ${ }^{80}$.

79 DOUGLAS, R. Law, liberty, and the pursuit of terrorism. Ann Arbor: The University of Michigan Press, 2014.

80 MOGUL, P. Jakarta attacks: indonesians share 'we are not afraid' \#KamiTidakTakut message on Twitter. International Business Times, jan. 2016. Available on: <https://www.ibtimes.co.uk/jakartaattacks-indonesians-share-we-are-not-afraid-kamitidaktakut-message-twitter-1537913>. 


\section{SUMmARY AND CONCLUSION}

Firstly, we deem worth reminding the challenges to assess the legal terminology from these legislation, even though we are familiar with legal terminology from Brazil, it soon became clear that the legal terms were quite different, and the dictionaries were invaluable companions. Nonetheless, we expect to have made ourselves clear enough to provide a good understanding of what those bills include, their differences and similarities. What was also challenging is the fact that US legislation on terrorism and criminal procedure is not concentrated in the Anti-terrorism and Effective Death Penalty Act of 1996 and the Patriot Act of 2001 as we expected it would be. Also, the Patriot Act did not prove itself the so called "game changer". Therefore, the results of this paper represent an initial effort of a broader research agenda on the impacts of terrorist attacks on societies and how to respond to them.

Future research could develop upon what are the possible effects of counter-terrorism legislation that is less protective of human rights on terrorism and terrorist attacks. Also, if, in fact, counter-terrorism legislation has any effect on terrorism and on the actual occurrence of terrorist attacks.

Furthermore, throughout this paper's analysis we were frequently confronted with a discourse about the risk society ${ }^{81}$ and its consequent sensation of fear and insecurity used by politicians and intellectuals to justify new methodologies, especially on constitutional and criminal laws. So much that we have to agree with $\mathrm{Ca}$ notilho on the necessity of clarifying the differences between the typical risks of a technological civilization, like nuclear, chemical, environmental and pharmaceutical risks, at large, part of our daily life, and the very different risk that comes from psychological and ideological dimensions, caused by the mere existence of the "other", the "enemy", the one that belongs to another political, ideological or religious "tribe". As previously mentioned, the latter has been used to legitimize preventive and repressive actions towards the implementation of a "criminal law of the risk", less protective of human rights. In other words, the psychological and ideological risks, grounded with the ideas of security and citizens' protection, are the arguments behind the

81 See more at BECK, Ulrich. Risk society: towards a new modernity. London: Sage Publications, 1992. precautionary principle and its consequent actions of combat against individuals and organizations that are the "embodiment" of those risks" ${ }^{82}$. Although it might be possible that constitutional and criminal laws need new paradigms to deal with the typical risks of a technological civilization and the terrorist phenomenon, compromising human rights standards and criminalizing the "other" for its mere existence do not seem adequate responses.

\section{References}

ANGLÍ, M. L. What does terrorism means? In: MASFERRER, A.; WALKER, C. Counter-terrorism, buman rights and the rule of law: crossing legal boundaries in defence of the state. Cheltenham: Edward Elgar, 2013.

ANTI-TERRORISM ACT. Anti-terrorism and effective death penalty act of 1996. Public Law 104-132. April 24, 1996. Available on: <https://www.congress.gov/104/ plaws/publ132/PLAW-104publ132.pdf $>$.

BECK, Ulrich. Risk society: towards a new modernity. London: Sage Publications, 1992.

BENNETT, A.; CHECKEL, J. T. Process tracing: from metaphor to analytic tool. Cambridge: Cambridge University Press, 2015.

BORGES, D. D. O princípio do desenvolvimento sustentável no direito internacional público. In: MANIGLIA, E. (Org.). 50 anos do estatuto da terra: 25 anos de direito agrário na UNESP. São Paulo: Cultura Acadêmica, 2014. p. 179-196.

BRAITHWAITE, A. The logic of public fear in terrorism and counter-terrorism. Journal of Police and Criminal Psychology, v. 28, p. 95-101, 2013. DOI 10.1007/s11896013-9126-x.

BREEDON, Jennifer. Redefining terrorism: the danger of misunderstanding the modern world's gravest threat. Revista de Direito Internacional, Brasília, v. 12, n. 2, 2015 p. 463-483.

CANOTILHO, J. J. G. Terrorismo e direitos fundamentais. In: CANOTILHO, J. J. G. Estudos sobre direitos fundamentais. São Paulo: Coimbra; Revista dos Tribunais,

82 Canotilho, J. J. G.. Terrorismo e direitos fundamentais. In Canotilho, J. J. G.. (2008). Estudos sobre Direitos Fundamentais. São Paulo: Coimbra Editora e Editora Revista dos Tribunais. pp. 240, 241. 
2008.

CHOMSKY, N. The culture of terrorism. Boston: South End Press, 1988.

CHOMSKY, N. International terrorism: image and reality. In: GEORGE, A. (Ed.). Western state terrorism. New York: Routledge, 1991. p. 12-38.

CONN, T. L. Use of secret evidence by government lawyers: balancing defendants' rights with national security concerns. Cleveland State Law Review, 2004. Available on: < http://engagedscholarship.csuohio.edu/cgi/ viewcontent. cgi?article $=1297 \&$ context $=$ clevstlrev $>$.

DOUGLAS, R. Law, liberty, and the pursuit of terrorism. Ann Arbor: The University of Michigan Press, 2014.

DOWLING, N. T. Protection of human rights under the United States constitution. The Annals of the American Academy of Political and Social Science, v. 243, p. 96-100, 1946. Available on: <http://www.jstor.org/ stable/1025061>.

FITZPATRICK, J. Speaking law to power: the war against terrorism and human rights. European Journal of International Law, v. 14, n. 2, apr. 2003.

FRIEDLAND, N.; MERARI, A. The psychological impact of terrorism: a double-edged sword. Polit Psychol, v. 6, p. 591-604, 1985.

GALLUP. Terrorism in the United States. Gallup. Available on: <http://www.gallup.com/poll/4909/terrorism-united-states.aspx $>$.

GALLUP. War on terrorism. Gallup. Available on: <http: / / www.gallup.com/poll/5257/War-terrorism.aspx?g_source $=$ terrorism $\% 202001 \& g_{-}$ medium $=$ search\&g_campaign $=$ tiles $>$.

GEORGE, A. Introduction. In: GEORGE, A. (Ed.). Western state terrorism. New York: Routledge, 1991. p. $1-11$.

GILL, L. The school of the Americas: military training and political violence in the Americas. Durham: Duke University Press, 2004.

GRONKE, et al. U.S. public opinion on torture: 20012009. Symposium: Terrorism and Human Rights, july 2010. DOI:10.1017/S1049096510000697.

GTD. Using GTD. Data collection methodology: data collection and the definition of terrorism. Global Terrorism Database. Available on: <https://www.start.umd. edu/gtd/using-gtd/>.

GTD. GTD ID: 200109110004. When: 2001-09-11. Country: United States. Global terrorism database. Available on: <https://www.start.umd.edu/gtd/search/IncidentSummary.aspx?gtdid $=200109110004>$.

GTD. GTD ID: 200109110005. When: 2001-09-11. Country: United States. Global terrorism database. Available on: <https://www.start.umd.edu/gtd/search/IncidentSummary.aspx?gtdid $=200109110005>$.

GTD. GTD ID: 200109110006. When: 2001-09-11. Country: United States. Global terrorism database. Available on: <https://www.start.umd.edu/gtd/search/IncidentSummary.aspx?gtdid $=200109110006>$.

GTD. GTD ID: 200109110007. When: 2001-09-11. Country: United States. Global terrorism database. Available on: <https://www.start.umd.edu/gtd/search/IncidentSummary.aspx?gtdid $=200109110007>$.

HAHN, R. W.; SUNSTAIN, C. R. The precautionary principle as a basis for decision making. The Economists' Voice, v. 2, n. 2, article 8, 2005.

HOFFMAN, L. Av Secretary of State for the Home Department. UKHL. 56 para 96, 2004.

HOFFMAN, B. Inside terrorism. New York: Columbia University Press, 2006. v. 2.

HOWIE, L. Terrorism, the worker and the city. Farnham: Gower, 2012.

JAMES, B. 9/11 Conspiracy theories: inside the lonely lives of truthers, still looking for their big break. International Business Times, sep. 2015. Available on: <http://www.ibtimes.com/911-conspiracy-theoriesinside-lonely-lives-truthers-still-looking-their-big-break-2091474>.

LENNON, G. Precautionary tales: suspicionless counter-terrorism stop and search. Criminology \& Criminal Justice, v. 15, n. 1, p. 44-62, 2013. Available on: <https://doi.org/10.1177/1748895813509637.>.

LONG, E. The anatomy of terrorism. New York: Free Press, 1990.

LUSTICK, I. S. Trapped in the war on terror. Philadelphia: University of Pennsylvania Press, 2006.

MASFERRER, A.; WALKER, C. Countering terrorism and crossing legal boundaries. In: MASFERRER, A.; WALKER, C. Counter-terrorism, human rights and the rule 
of law: crossing legal boundaries in defence of the state. Cheltenham: Edward Elgar, 2013.

MASFERRER, A. The fragility of fundamental rights in the origins of modern constitutionalism: its negative impact in protecting human rights in the "war on terror" era. In: MASFERRER, A.; WALKER, C. Counter-terrorism, human rights and the rule of law: crossing legal boundaries in defence of the state. Cheltenham: Edward Elgar, 2013.

MOGUL, P. Jakarta attacks: indonesians share 'we are not afraid' \#KamiTidakTakut message on Twitter. International Business Times, jan. 2016. Available on: $<$ https://www.ibtimes.co.uk/jakarta-attacks-indonesians-share-we-are-not-afraid-kamitidaktakut-messagetwitter-1537913>.

PATRIOT ACT. Uniting and strengthening America by providing appropriate tools required to intercept and obstruct terrorism (USA PATRIOT ACT) act of 2001. Available on: <https://www.gpo.gov/fdsys/pkg/ BILLS-107hr3162enr/pdf/BILLS-107hr3162enr.pdf>.

PELLET, S. A ambiguidade da noção de terrorismo. In: BRANT, L. N. C. (Coord.). Terrorismo e direito: os impactos do terrorismo na comunidade internacional e no Brasil. Rio de Janeiro: Forense, 2003.

PEW RESEARCH CENTER. Americans open to dissenting views on the war on terrorism. Pew Research Center. October 4, 2001. Available on: <http://www.people-press. org/2001/10/04/americans-open-to-dissenting-viewson-the-war-on-terrorism/>.

PEW RESEARCH CENTER. American psyche reeling from terror attacks. Pew Research Center. September 19, 2001. Available on: <http://www. people-press.org/2001/09/19/other-important-findings-and-analyses-48/> .

RAND. Database scope. Database of worldwide terrorism incidents (RDWTI). Available on: <https://www.rand. $\mathrm{org} / \mathrm{nsrd} / \mathrm{projects} /$ terrorism-incidents/about/definitions.html>.

RAND. Terrorism incidents database search. Incident detail: Sep 11, 2001. Washington, DC, United States. Al Qaeda. Database of Worldwide Terrorism Incidents (RDWTI). Available on: <http://smapp.rand.org/ rwtid/incident_detail.php?id $=7759>$.

RAND. Terrorism incidents database search. Incident detail: Sep 11, 2001. Shanksville, United States. Al Qa- eda. Database of Worldwide Terrorism Incidents (RDWTI). Available on: $<$ http://smapp.rand.org/rwtid/incident_ detail.php?id $=7758>$.

RAND. Terrorism incidents database search. Incident detail: Sep 11, 2001. New York City, United States. Al Qaeda. Database of Worldwide Terrorism Incidents (RDWTI). Available on: <http://smapp.rand.org/rwtid/incident_ detail.php?id $=7757>$.

RAPOPORT, D. The four waves of rebel terror and September 11. Anthropoetics, v. 8, n. 1, spring/summer 2002. Available on: <http://anthropoetics.ucla.edu/ ap0801/terror/>.

SCHMID, A. Terrorism: the definitional problem. Case Western Reserve Journal of International Law, v. 36, n. 375, 2004. Available on: <https:// scholarlycommons.law.case.edu/cgi/viewcontent. c gi? article $=1400 \&$ context $=$ jil $>$.

SECRET evidence in the War on Terror. Harvard Law Review, v. 118, n. 6, p. 1962-1984, 2005. Available on: <http://www.jstor.org.ezproxy.its.uu.se/stable/4093289>.

SHANTY, F. Impact of 9/11 on U.S. public opinion. In: GOLDMAN, J. (Ed.). The war on terror encyclopedia: from the rise of $\mathrm{Al}$ Qaeda to 9/11 and beyond. ABC-CLIO; LLC, 2014.

SHOR, et al. Terrorism and state repression of human rights: a cross-national time-series analysis. International Journal of Comparative Sociology, v. 55, n. 4, 2014.

SIKKINK, K. Mixed signals: U.S. human rights policy and Latin America. Ithaca: Cornell University Press, 2004.

STATISTIC BRAIN. 9/11 death statistics. Statistic Brain, nov. 2015. Available on: <https://www.statisticbrain. com/911-death-statistics/>.

STERN, J.; WIENER, J. Precaution against terrorism. Journal of Risk Research, v. 9, n. 4, p. 393-447, 2006. Available on: <https://www.belfercenter.org/sites/default/ files/legacy/files/Precaution $\% 20$ Against $\% 20$ Terrorism.pdf $>$.

THE GUARDIAN. Text of George Bush's speech: State of the Union Address. The Guardian, sept. 21, 2001. Available on: <https://www.theguardian.com/ world/2001/sep/21/september11.usa13>.

UNITED STATES OF AMERICA. Patterns of global ter- 
rorism 2001. United States Department of State, 2002. Available on: < https://www.state.gov/documents/organization/10319.pdf $>$.

UNITED STATES OF AMERICA. Patterns of global terrorism 2003. United States Department of State, 2004. Available on: <https://www.state.gov/documents/organization/31932.pdf $>$.

UNITED NATIONS. Rio declaration on environment and development 1992. The United Nations conference on environment and development. Rio de Janeiro, 3, to 14, jun. 1992. Available on: <http://www.unesco.org/education/pdf/RIO_E.PDF $>$.

UNHR. Status of ratification interactive dashboard. ratification of 18 international buman rights treaties. United Nations Human Rights: Office of the High Commissioner. Available on: < http://indicators.ohchr.org/>.

UNSC. United Nations Security Council Resolution 1373. Adopted by the Security Council at its 4385th meeting, on 28 September 2001. Available on: <https://www. unodc.org/pdf/crime/terrorism/res_1373_english. pdf $>$.

WHITE, J. Abu Ghraib tactics were first used at Guantanamo. The Washington Post, july 14, 2005. Available on: <http://www.washingtonpost.com/wp-dyn/content/ article/2005/07/13/AR2005071302380.html>.

WILKINSON, P. Terrorism versus democracy: the liberal state response. 3. ed. Taylor \& Francis, 2011.

WPB. Highest to lowest: prison population total. World Prison Brief. Institute for Criminal Policy Research. Available on: < http://www.prisonstudies.org/highestto-lowest/prison-population-total?field_region_taxonomy_tid $=$ All $>$.

WPO. American and international opinion on the rights of terrorism suspects. Principal Investigator: Steven Kull. The World Public Opinion, 2006. Available on: <http:// www.worldpublicopinion.org/pipa/pdf/jul06/TerrSuspect_Jul06_rpt.pdf>. 
Para publicar na Revista de Direito Internacional, acesse o endereço eletrônico www.rdi.uniceub.br ou www.brazilianjournal.org.

Observe as normas de publicação, para facilitar e agilizar o trabalho de edição. 